\title{
Transgenic corn decreased total and key storage and lipid transport protein levels in honey bee hemolymph while seed treatment with imidacloprid reduced lipophorin levels
}

Daniel Nicodemo, David De Jong, Leriana Garcia Reis, Joyce Mayra Volpini de Almeida, Anderson Augusto dos Santos \& Lucas Aparecido Manzani Lisboa

To cite this article: Daniel Nicodemo, David De Jong, Leriana Garcia Reis, Joyce Mayra Volpini de Almeida, Anderson Augusto dos Santos \& Lucas Aparecido Manzani Lisboa (2018) Transgenic corn decreased total and key storage and lipid transport protein levels in honey bee hemolymph while seed treatment with imidacloprid reduced lipophorin levels, Journal of Apicultural Research, 57:2, 321-328, DOI: 10.1080/00218839.2017.1391530

To link to this article: https://doi.org/10.1080/00218839.2017.1391530

Published online: 19 Dec 2017.

Submit your article to this journal $\longleftarrow$

Џll Article views: 246

View Crossmark data ¿ 


\title{
ORIGINAL RESEARCH ARTICLE
}

\section{Transgenic corn decreased total and key storage and lipid transport protein levels in honey bee hemolymph while seed treatment with imidacloprid reduced lipophorin levels}

\author{
Daniel Nicodemo ${ }^{a *}$ (D), David De Jong ${ }^{b}$ (D), Leriana Garcia Reis ${ }^{a}$, Joyce Mayra Volpini de Almeida ${ }^{c}$ (D), Anderson Augusto \\ dos Santos ${ }^{\mathrm{a}}$ and Lucas Aparecido Manzani Lisboa ${ }^{\mathrm{a}}$ (D) \\ ${ }^{a}$ Faculdade de Ciências Agrárias e Tecnológicas, Universidade Estadual Paulista, Dracena, Brazil; ${ }^{b}$ Departamento de Genética, Faculdade de \\ Medicina, Universidade de São Paulo, Ribeirão Preto, Brazil; 'Entomologia, Departamento de Biologia, Faculdade de Filosofia, Ciencias e Letras, \\ Universidade de São Paulo, Ribeirão Preto, Brazil
}

(Received I June 2017; accepted 9 October 2017)

\begin{abstract}
Pollen substitutes are currently widely used in apiculture because of a lack of natural forage and an increasing need for bees for pollination services. A major concern in the confection of bee diets is whether specific ingredients, such as GMO grain, or contaminants such as pesticides that are applied to crops, negatively impact bee health. We measured hemolymph protein levels and the lifespan of honey bees fed on diets containing non-hybrid (IAC-Airan), hybrid (AG 7088) or transgenic (AG 8088YG) maize, the seeds of which had been treated with fipronil, imidacloprid or left untreated. Corn from these plantings was harvested, dried and finely ground, and then used for the preparation of corn-based diets. Groups of 100 newly emerged bees were placed in cages, where the diets were offered ad libitum. Honey bee lifespan was similar for all the corn diets, though shorter than for bees fed beebread and longer than for bees fed only honey. Total protein in the hemolymph of bees fed with transgenic maize was I5\% lower than in bees fed on non-hybrid maize; lipophorin and vitellogenin, were more reduced, by over 30\%. Irrespective of corn variety, imidacloprid resulted in over $25 \%$ lower levels of lipophorin compared with the control. Lower storage and transport protein levels would compromise the ability of the bees to rear brood and develop an adequate immune response to pathogen challenge. Consequently, transgenic maize, as well as any maize produced from seed treated with imidacloprid should not be included as ingredients in honey bee diets.
\end{abstract}

Maíz transgénico disminuí niveles de proteínas claves de almacenamiento y transporte de lípidos en hemolinfa de abejas melíferas así como el tratamiento de semillas con imidacloprid reduce los niveles de lipoforina

Substitutos del polen actualmente son utilizados en larga escala en la apicultura por causa de la falta de alimento natural y un aumento en la necesidad de abejas para servicios de polinización. Una preocupación importante en la confección de dietas para las abejas es si ingredientes específicos, como granos OGM, o contaminantes como plaguicidas aplicados a los cultivos, impactan negativamente sobre la salud de la abeja. Nosotros medimos los niveles de proteína en la hemolinfa y el tiempo de vida de abejas melíferas alimentadas con dietas conteniendo maíz no-hibrido (IAC-Airan), híbrido (AG 7088) o transgénico (AG 8088YG); durante la siembra de estos cultivos las semillas fueran tratadas con fipronil, imidacloprid o sin ningún tratamiento. Muestra de maíz de estas plantaciones fueran cosechadas, secadas, molidas y después utilizadas para preparar las dietas basadas en maíz. Grupos de 100 abejas recién emergidas fueran colocadas en jaulas y las dietas fueran ofrecidas a libre consumo. El tiempo de vida de las abejas fue similar para todas las dietas con maíz, pero más corto del que para abejas alimentadas con pan de la abeja y mayor en comparación con abejas alimentadas solamente con miel. Los niveles de proteína total en la hemolinfa de las abejas alimentadas con maíz transgénico fue $15 \%$ menor en comparación con abejas alimentadas con maíz no-hibrido; lipoforina y vitelogenina presentaron más reducción, cerca de 30\%. Independientemente de la variedad de maíz, imidacloprid resulto en más de $25 \%$ de la reducción de lipoforina, comparada con el control. Niveles menores de proteínas de almacenamiento y transporte puede comprometer la habilidad de las abejas en producir cría y desarrollar una respuesta inmunológica adecuada cuando confrontada con un desafío de patógenos. Por lo tanto, maíz transgénico y cualquier maíz producido utilizando semillas tratadas con imidacloprid no deben ser utilizados como ingredientes en dietas de abejas melíferas.

Keywords: Apis mellifera; artificial diet; fipronil; genetically modified organism; neonicotinoid; vitellogenin

\section{Introduction}

In addition to natural seasonal variations that directly interfere with the availability of nectar and pollen for bees, anthropogenic effects on ecosystems and agroecosystems can result in unfavorable conditions for nutritional subsistence due to intensification of food shortage periods; this includes extensive monoculture plantings with floral features that do not meet the nutritional demand of bees (Cock et al., 2013; Winston, 1987). The use of artificial diets is increasing worldwide

*Corresponding author. Email: nicodemo@dracena.unesp.br 
in order to maintain the bees and to prepare them for honey production and pollination services (Brodschneider \& Crailsheim, 20I0; Tomlinson, Dixon, Didham, \& Bradshaw, 2017).

Although nutritional requirements of honey bees for carbohydrates, proteins, lipids, vitamins, minerals and water are well known (Haydak, 1970; Herbert, 1992; Huang, 20l0), artificial diets are often empirically formulated to provide energy and protein requirements for honey bee colony maintenance and development. Beekeepers have traditionally used refined sucrose, high fructose corn syrup and soy-based products (Somerville, 2005). The choice of ingredients or substitutes is contingent on availability and prices.

In Brazil, approximately $80 \%$ of all cultivated areas are occupied with soybean, maize and sugarcane crops (IBGE, 2016). These crops are not utilized for honey and pollen production (Knopper, Dan, Reisig, Johnson, \& Bowers, 2016). Nevertheless, artificial diets for bees are prepared using the products of these crops. All three cultures are susceptible to specific insect pests, such as leafhoppers, termites and borers, which are controlled with insecticides such as fipronil and imidacloprid (Andrei, 2013; Simon-Delso et al., 2015). These persistent and systemic insecticides are especially toxic for bees, manifesting lethal and sublethal effects (Nicodemo et al., 20l4). Bees can be directly affected by insecticide product application to plantings when they feed on floral resources of treated crops or even when they are fed diets formulated with products obtained from these crops (Decourtye et al., 2004; El Hassani, Dacher, Gauthier, \& Armengaud, 2005; Iwasa, Motoyama, Ambrose, \& Roe, 2004; Johnson, Ellis, Mullin, \& Frazier, 2010; Mayer \& Lunden, 1999; Roat et al., 2013).

Maize and soybean are the main genetically modified (GMO) crops used worldwide. Herbicide tolerance and insect resistance are the principle traits in these GMO crops (Qaim, 2009). There is evidence that nectar, pollen and products obtained from GMO crops can be harmful to bee health (Han, Niu, Lei, Cui, \& Desneux, 20I0a; de Maagd, Bravo, \& Crickmore, 200I; RamirezRomero, Desneux, Decourtye, Chaffiol, \& PhamDelègue, 2008; Sabugosa-Madeira, Abreu, Ribeiro, \& Cunha, 2007). If floral resources of transgenic plants negatively impact the health of bees, diets formulated with ingredients obtained from these plants also are potentially harmful.

We examined whether honey bee diets based on transgenic vs. non-transgenic maize treated or not with imidacloprid or fipronil at sowing would affect bees by measuring their hemolymph proteins and lifespan.

\section{Material and methods}

\section{Maize seeding and insecticide application}

Maize seeds of non-hybrid (IAC-Airan), hybrid (AG7088) and transgenic (AG8088YG) cultivars were sown in stands of 55,000 plants per ha with fertilization conducted according to Raij, Cantarella, Quaggio, and Furlani (1997) in Dracena, Brazil (21 $27^{\circ} 37^{\prime \prime}$ S latitude, $51^{\circ} 33^{\prime} 21^{\prime \prime} \mathrm{W}$ longitude, and $421 \mathrm{~m}$ altitude).

The three cultivars were grown in $300 \mathrm{~m}^{2}$ fields that were at least $600 \mathrm{~m}$ away from other maize cultivar fields. Each area of a single cultivar was subdivided into three plots of $100 \mathrm{~m}^{2}$ for insecticide application.

In the first plot for each area, application of a commercial product that included fipronil as its active ingredient (a.i.) was conducted during furrow planting using $80 \mathrm{~g} \mathrm{ha}^{-1}$ of a.i. diluted in water for the application of $250 \mathrm{~L} \mathrm{ha}^{-1}$ of this solution, according to the manufacturer's suggestion for the control of Diabrotica speciosa (Coleoptera: Chrysomelidae) (Melhorança et al., 2010; Regent 800 WG, 2002).

For the second plot for each area with the same maize cultivar, seeds were treated with an insecticide that included imidacloprid as its a.i. Before sowing, seeds were treated with a proportion of $490 \mathrm{~g}$ of a.i. $100 \mathrm{~kg}^{-1}$ of seeds to control D. speciosa (Gaucho, 1996; Melhorança et al., 2010). In the third plot for each area, no insecticides were used. No other pesticides were used during the development of the maize plants in the three areas.

\section{Diets and feeding}

Nine maize-based diets were prepared (three maize cultivars $x$ two insecticides and a control). Diets consisted of 8 parts very finely ground cornmeal and 2 parts organic honey. To compare the tested diets with natural bee feeding conditions, 8 parts beebread and 2 parts organic honey were used to prepare a positive control diet. For the protein-negative control diet, only organic honey was fed. Diets were offered ad libitum using feeders inside plastic screened cages $(20 \times 13 \times 13 \mathrm{~cm})$ in portions of $10 \mathrm{~g}$ per cage, with food exchange every two days. Water was also supplied to all cages.

\section{Bromatological analysis}

Crude protein (CP) content of dietary ingredients was determined and expressed in dry matter (DM), with three replicates for each ingredient (Association of Official Analytical Chemists [AOAC], 1990; Silva \& Queiroz, 2006).

\section{Honey bees}

Brood combs were obtained from a single honey bee colony housed in a standard Langstroth hive, containing sealed brood ready to emerge. This hive was fed previously for two months with $50 \%(\mathrm{w} / \mathrm{v})$ sucrose syrup to stimulate brood production. Each comb was placed in a screened cage and stored in an incubator at $33{ }^{\circ} \mathrm{C}$ with $70 \%$ relative humidity for $36 \mathrm{~h}$. Under the same incubator conditions, each plastic screened cage was stocked with 100 newly emerged adult worker honey bees. The experiments were repeated three times. 


\section{Hemolymph protein levels}

After adult workers emerged, a sample of 10 bees was collected from each cage to determine the concentration of proteins in the pool of bee hemolymph on the day of emergence (day 0 ) and another 10 bees on day 7 .

Hemolymph was collected with the aid of micropipettes inserted into a small cut made at the base of the bee's wing with microscissors and transferred to microcentrifuge tubes with phenylthiocarbamide (PTC) and protease inhibitor, using microcapillary tubes previously washed in a $0.1 \%$ (wt:vol) phenylthiourea solution in water.). Hemolymph samples were centrifuged at I,500 rpm for $4 \mathrm{~min}$ at $4{ }^{\circ} \mathrm{C}$. The supernatant was removed and frozen at $-20{ }^{\circ} \mathrm{C}$. Total protein quantification was performed by the Bradford method (1976), Quantification of the samples was made using a Beckman Coulter DXT-880-multimode detector spectrophotometer at $595 \mathrm{~nm}$ with three replicates, and a standard curve was constructed using bovine serum albumin (Cremonez, De Jong, \& Bitondi, 1998).

\section{Analysis of hemolymph protein profiles}

For evaluation of newly emerged (day 0) and seven-dayold honey bee hemolymph protein profiles, I $\mu$ l of hemolymph was dissolved in sample buffer with $0.25 \mathrm{M}$ Tris$\mathrm{HCl}, \mathrm{pH} 6.8$, containing $70 \%$ sucrose, $0.25 \%$ sodium dodecyl sulfate (SDS), $0.1 \%$ bromophenol blue and $5 \% \beta$ mercaptoethanol. Samples were submitted to thermal denaturation, and after cooling, they were applied to separation gels with $7.5 \%$ polyacrylamide (Laemmli, 1970).

The proteins myosin $(205 \mathrm{kDa}), \quad \beta$-galactosidase ( I $16 \mathrm{kDa})$, phosphorylase b (97), BSA (66 kDa), ovalbu$\min (45 \mathrm{kDa})$ and carbonic anhydrase $(29 \mathrm{kDa})$ were used as molecular mass markers. For quantitative evaluation of lipophorin and vitellogenin proteins, SDS-PAGE gels were scanned and individual profiles of each sample were analyzed by densitometry using Adobe Photoshop 7.0 Software, with three replicates. Data was represented as arbitrary optical density units (D.U.).

\section{Evaluation of longevity}

One hundred bees per cage were placed in an incubator with controlled temperature $\left(33^{\circ} \mathrm{C}\right)$ and humidity (70\%). At day $0,10 \mathrm{~g}$ of protein food was offered to the bees in feeders inside the plastic pots. This diet was renewed every two days. Once a day, dead bees were counted and removed until the all bees had died.

\section{Statistical analysis}

Data were submitted to statistical analysis and the effects were considered significant at $p \leq 0.05$. Two models were applied to data. The first model comprises the II treatments for comparisons with controls (beebread and honey based-diets), as described below:

$$
y_{\mathrm{ij}}=\mu+\alpha_{\mathrm{i}}+\mathrm{e}_{\mathrm{ij}} .
$$

where $y_{i j}=$ response variable of bees fed diets (i) in replication (j). $\mu=$ overall mean values for $y \cdot a_{i}=$ fixed effect of diets. $\mathrm{e}_{\mathrm{ij}}=$ error term.

The second model was used to study the interactions between the maize type and insecticide, except for longevity evaluation, as follows:

$$
y_{\mathrm{ijk}}=\mu+\alpha_{\mathrm{i}}+\delta_{\mathrm{j}}+(\alpha \times \delta)_{\mathrm{ij}}+\mathrm{e}_{\mathrm{ijk}} .
$$

where $y_{i j k}=$ response variable of bees fed maize types (i) and submitted to different insecticides (j) in replication (j). $\mu$ = overall mean values for $y \cdot a_{\mathrm{i}}=$ fixed effect of diets. $\delta_{\mathrm{j}}=$ fixed effect of insecticide. $(a \times \delta)_{\mathrm{ij}}=$ interaction of maize type with insecticide. $e_{i j k}=$ error term.

All response variables were submitted to analysis of variance, and the Tukey test was used for multiple comparisons. To evaluate the longevity of the bees, the Kaplan-Meier non-parametric method was used. Data were processed with SAS software (SAS Institute, 2003).

\section{Results}

In the analysis of the II dietary ingredients, beebread $(28.8 \% \pm 0.7)$ and honey $(0.4 \% \pm 0.03)$ presented the highest and lowest protein levels $(p<0.05)$, respectively. In the evaluation of maize types, treated with insecticides fipronil and imidacloprid or left untreated, no difference was observed for crude protein content, with a general average of $10.5 \% \pm 0.1$ (Table I).

Total protein concentration in the hemolymph of adult bees on the day that they emerged (day 0) was $16.0 \pm 2.1 \mu \mathrm{g} / \mathrm{l}$ From day 0 to day 7 , bees were fed experimental diets. Based on the analyses conducted at the end of the 7-day period, we observed that the highest value $(p<0.05)$ of total proteins in the hemolymph $(22.6 \pm 2.3 \mu \mathrm{g} / \mu \mathrm{l})$ was obtained when beebread was offered to the bees. With the honey-based diet, the mean value of total proteins in the hemolymph (5.5 $\pm 0.7 \mu \mathrm{g} / \mu \mathrm{l})$ did not differ significantly from that of bees fed on any of the corn-based diets, which additionally did not differ from each other $(p>0.20)$.

Considering only the maize-based diets, the possible interactions and the main effects were studied. No difference was found regarding the interactions between maize types and insecticides (Table 2). For the main effect type of insecticide, we found that whether insecticide was used or not used did not influence hemolymph protein concentration for bees fed on maize-based diets. Concerning maize types only, we observed that total hemolymph protein concentration for the bees was lower $(p<0.05)$ when the transgenic cultivar was used compared with the non-hybrid cultivar. Non-transgenic hybrid maize did not differ from the other two corn cultivars $(p>0.20)$.

Through qualitative analysis of the polyacrylamide gels, we found that the highest protein levels occurred 
Table I. Crude protein content as a percentage in dry matter of the maize ingredients used in experimental diets for honey bees produced from seeds that had been treated or not with insecticide at planting.

\begin{tabular}{lcccc}
\hline & & \multicolumn{2}{c}{ Insecticide } & \\
\cline { 3 - 4 } Maize types & No insecticide & Fipronil & Imidacloprid & Overall average \\
\hline Non-hybrid & $10.2 \pm 0.3 \mathrm{~b}^{\mathrm{a}}$ & $10.1 \pm 0.2 \mathrm{~b}$ & $10.7 \pm 0.2 \mathrm{~b}$ & $10.3 \pm 0.2$ \\
Hybrid & $10.6 \pm 0.1 \mathrm{~b}$ & $10.8 \pm 0.2 \mathrm{~b}$ & $10.9 \pm 0.5 \mathrm{~b}$ & $10.8 \pm 0.2$ \\
Transgenic & $10.3 \pm 0.2 \mathrm{~b}$ & $10.0 \pm 0.7 \mathrm{~b}$ & $11.1 \pm 0.1 \mathrm{~b}$ & $10.4 \pm 0.3$ \\
Overall average & $10.4 \pm 0.1$ & $10.2 \pm 0.2$ & $10.9 \pm 0.2$ & $10.5 \pm 0.1$ \\
\hline
\end{tabular}

${ }^{a}$ Results are expressed as the mean \pm standard error of the mean. Means followed by different letters differ from each other $(p<0.05)$ as indicated by the Tukey test.

Table 2. Concentration of total proteins $(\mu \mathrm{g} / \mu \mathrm{l})$ in the hemolymph of seven-day-old adult honey bees fed from day 0 with cornbased diets derived from corn plants treated with fipronil or imidacloprid or left untreated at sowing.

\begin{tabular}{lcccc}
\hline & & \multicolumn{2}{c}{ With insecticide } & \\
\cline { 3 - 4 } Maize types & Without insecticide & Fipronil & Imidacloprid & Overall average \\
\hline Non-hybrid & $7.9 \pm 0.6$ & $8.2 \pm 0.8$ & $7.3 \pm 0.7$ & $7.8 \pm 0.4 \mathrm{a}^{\mathrm{a}}$ \\
Hybrid & $6.7 \pm 0.1$ & $7.1 \pm 0.5$ & $7.9 \pm 0.7$ & $7.2 \pm 0.3 \mathrm{ab}$ \\
Transgenic & $6.6 \pm 0.6$ & $6.7 \pm 0.6$ & $6.4 \pm 0.3$ & $6.6 \pm 0.3 \mathrm{~b}$ \\
Overall average & $7.0 \pm 0.3$ & $7.3 \pm 0.4$ & $7.2 \pm 0.4$ & $7.2 \pm 0.2$ \\
\hline
\end{tabular}

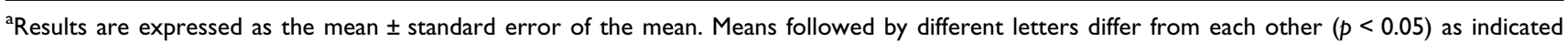
by the Tukey test.

at day 0 . After seven days of the bees being fed the experimental diets, the diet consisting of beebread allowed the bees to obtain the highest protein density profile. On the other hand, along with it being the diet containing the lowest protein content, the honey-based diet provided the lowest protein profile density in the hemolymph among all the diets.

On day 0 , the densitometric quantification of lipophorin present in the hemolymph of the bees was $233.7 \pm 3.4$ D.U. Analyzing the II diets on day 7, the concentration of this protein was higher $(p<0.05)$ when bees were fed a beebread diet (2II.I \pm 3.6 D.U.) than when they were fed a honey-based diet (108.0 \pm 6. .I D.U.). No difference was observed $(p>0.20)$ for lipophorin levels of bees fed on the nine maize-based diets.

No effect of interactions between maize types and insecticides was observed for lipophorin levels. Regarding only the main effect type of insecticide, lipophorin levels in bee hemolymph were lower $(p<0.05)$ when the bee feed was made from corn from maize plants treated at planting with imidacloprid when compared with the untreated plants (Table 3). Plants treated with fipronil promoted intermediate results that did not differ from plants treated with imidacloprid or untreated plants $(p>0.20)$. Considering only the maize types, we observed that lipophorin levels were lower $(p<0.05)$ when the bees were fed with transgenic maize compared to the bees fed with non-hybrid or non-transgenic hybrid maize.

The densitometric quantification of vitellogenin in the hemolymph of newly emerged bees was 79.2 \pm 4.8 D.U. For the analyses on day 7 , the concentration of vitellogenin was higher when bees were fed a beebread diet (I62.4 \pm 5.4 D.U.), while the lowest concentration values were observed with honey-based diets (23.6 \pm I.0 D.U.).

No effect of maize and insecticide interactions on vitellogenin protein levels was observed. The main effect type of insecticide also did not promote differences in vitellogenin protein levels (Table 4). However, in the analysis of the maize types, the concentration of vitellogenin was lower $(p<0.05)$ in bees fed on transgenic compared with non-hybrid maize. The concentration of vitellogenin found in the hemolymph of bees fed on non-transgenic hybrid maize did not differ from the concentration of vitellogenin found in the hemolymph of bees fed on non-hybrid and transgenic maize-based diets $(p>0.20)$.

Longevity increased for bees fed on beebread and decreased for bees fed on honey (Table 5). The longevity of bees fed on maize-based diets ranged from 19 to $2 \mathrm{l}$ days, and no difference $(p>0.20)$ was observed between bees fed on maize-based diets that were obtained from transgenic, hybrid and non-hybrid corn treated with fipronil or imidacloprid or left untreated.

\section{Discussion}

We did not find a superiority of crude protein content for any maize cultivar. Pollen, the common source of protein in bee food, has 2-4 times more protein than corn (Herbert \& Shimanuki, 1978). Therefore, it is not possible to fully replace pollen with maize as the only ingredient in a diet. However, maize can be used in the composition of bee diets because it is easily found on 
the market and typically cheaper than other bee diet ingredients (favoring the development of lower cost diets). Maize has all the essential amino acids for honey bees except tryptophan (De Groot, 1953; Rostagno et al., 2005).

As expected, honey had the lowest protein content of all ingredients used in the diets; therefore, honey cannot be the sole ingredient of a honey bee diet if colonies have insufficient pollen (Somerville, 2005). However, this natural energetic food is important for honey bees when they feed their larvae (Ellis \& Hayes, 2009; Herbert \& Shimanuki, 1978).

As holometabolous insects, the protein need for honey bees is higher for their brood compared with adult insects, although workers can benefit the health and development of the brood they feed by consuming protein (Crailsheim, 1990). Nurse bees need protein to complete the development of hypopharyngeal glands and produce worker or royal jelly (Alqarni, 2006; Maurizio, 1954; Pernal \& Currie, 2000) and thoracic musculature (Hersch, Crewe, Hepburn, Thompson, \& Savage, 1978).

At seven days old, bees should have high levels of protein in their hemolymph to appropriately feed larvae. Protein levels in bees fed the corn-based diets could have been affected by differences in consumption compared to the beebread diet. We did not measure consumption; however, Cremonez et al. (1998) found similar consumption by caged bees of a beebread compared to a corn meal diet. Protein levels in the hemolymph was similar for bees fed on all three varieties of corn, independent of whether the seeds had been treated or not with pesticide (Table 2). The protein titer in the honey bee hemolymph is related to the protein content of the diet (De Jong, da Silva, Kevan, \& Atkinson, 2009). Cremonez et al. (1998) observed that honey bees fed on diets based on corn meal had a significant reduction of protein hemolymph tiers compared to bees fed on diets based on beebread, soybean and yeast or pollen, though it was superior to sucrose.

On the market, most maize seeds available for commercialization are transgenic hybrids, which are mainly used because of higher yields, rather than to improve grain quality (Wolfenbarger \& Phifer, 2000). However, higher maize protein content, including higher lysine content via the development of transgenic maize varieties, can promote better nutritive value of this dietary ingredient (Tang et al., 20I3). In our study, no differences were observed regarding protein content among maize cultivars. Therefore, we did not expect to observe differences in the protein titers of the honey bee hemolymph. As there was no difference between protein crude content in all evaluated maize based diets, we inferred that other factors (not protein content) affected the amount of protein in the hemolymph of the bees.

The YieldGard varieties, such as the transgenic maize cultivar AG8088YG that we evaluated, were developed to provide resistance to lepidopteran and coleopteran pests by producing Bt proteins known as Cry proteins. When these insects attack maize plants, their digestive enzymes activate the toxic form of this protein, which acts quickly to damage the larvae (Vidal, Kuhlmann, \& Edwards, 2005). In a meta-analysis consisting of 25 studies that independently assessed potential effects of Bt Cry proteins on honey bee survival, Duan, Marvier, Huesing, Dively, and Huang (2008) did not observe any direct negative effects of $\mathrm{Bt}$ crops on honey bees.

Evaluation of lethal effects is very important; however, it cannot be exclusively used to determine whether any product impairs the health of an animal species. Sublethal effects should also be taken into account. In this case, the type of Cry toxin and the vegetable component used in honey bee feeding, such as pollen, nectar, grains, etc., must be considered on a case-by-case analysis (Malone \& Pham-Delègue, 200I).

Lipophorin is a lipoprotein responsible for the transport of lipids between absorption sites in the intestine and deposition sites in body fat cells or for use in muscles and other tissues (Chino \& Downer, 1982). Vitellogenin is a glycolipoprotein whose synthesis peaks when bees are 5-15 days old when the bees normally feed brood. In addition, vitellogenin influences a honey bee's lifespan, immunity, zinc transport and larval food synthesis (Amdam et al., 2004, 2005; Amdam, Norberg, Hagen, \& Omholt, 2003). The amount of vitellogenin present in hemolymph is influenced by the quantity and quality of food that bees have available (Bitondi \& Simões, 1996). Concentrations of both of these aforementioned proteins were reduced by more than $30 \%$

Table 3. Densitometric quantification, measured in arbitrary optical density units (D.U.), of the band intensity corresponding to lipophorin on an SDS-PAGE gel of the hemolymph of seven-day-old honey bees fed from emergence with corn-based diets derived from corn plants treated with fipronil or imidacloprid or left untreated at sowing.

\begin{tabular}{|c|c|c|c|c|}
\hline \multirow[b]{2}{*}{ Maize types } & \multirow[b]{2}{*}{ Without insecticide } & \multicolumn{2}{|c|}{ With insecticide } & \multirow[b]{2}{*}{ Overall average } \\
\hline & & Fipronil & Imidacloprid & \\
\hline $\begin{array}{l}\text { Non-hybrid } \\
\text { Hybrid } \\
\text { Transgenic } \\
\text { Overall average }\end{array}$ & $\begin{array}{l}188.3 \pm 1.4 \\
198.6 \pm 4.8 \\
\mid 47.2 \pm 8.4 \\
\mid 78.0 \pm 8.3 \mathrm{a}^{\mathrm{a}}\end{array}$ & $\begin{array}{l}177.9 \pm 2.2 \\
159.5 \pm 8.8 \\
113.6 \pm 3.3 \\
150.3 \pm 10.0 \mathrm{ab}\end{array}$ & $\begin{array}{l}169.8 \pm 3.2 \\
109.0 \pm 4.5 \\
107.6 \pm 2.5 \\
128.8 \pm 10.4 b\end{array}$ & $\begin{array}{l}178.6 \pm 2.9 \mathrm{~A} \\
155.7 \pm 13.3 \mathrm{~A} \\
122.8 \pm 6.7 \mathrm{~B} \\
152.4 \pm 6.6\end{array}$ \\
\hline
\end{tabular}

${ }^{a}$ Results are expressed as the mean \pm standard error of the mean. Means followed by different letters in the right column or in the bottom line differ from each other $(p<0.05)$ as indicated by the Tukey test. 
Table 4. Densitometric quantification, measured in arbitrary optical density units (D.U.), of band intensity corresponding to vitellogenin on a SDS-PAGE gel of the hemolymph of seven-day-old honey bees fed from birth with corn-based diets derived from corn plants treated with fipronil or imidacloprid or left untreated at sowing.

\begin{tabular}{|c|c|c|c|c|}
\hline \multirow[b]{2}{*}{ Maize types } & \multirow[b]{2}{*}{ No insecticide } & \multicolumn{2}{|c|}{ Insecticide } & \multirow[b]{2}{*}{ Overall average } \\
\hline & & Fipronil & Imidacloprid & \\
\hline $\begin{array}{l}\text { Non-hybrid } \\
\text { Hybrid } \\
\text { Transgenic } \\
\text { Overall average }\end{array}$ & $\begin{array}{l}59.0 \pm 0.9 \\
61.7 \pm 1.0 \\
26.6 \pm 2.3 \\
49.1 \pm 5.7\end{array}$ & $\begin{array}{l}41.6 \pm 1.3 \\
37.8 \pm 5.7 \\
36.5 \pm 3.3 \\
38.6 \pm 2.1\end{array}$ & $\begin{array}{l}59.8 \pm 1.1 \\
33.4 \pm 4.2 \\
39.3 \pm 0.7 \\
44.2 \pm 4.2\end{array}$ & $\begin{array}{l}53.4 \pm 3.0 \mathrm{~A}^{\mathrm{a}} \\
44.3 \pm 4.9 \mathrm{AB} \\
34.1 \pm 2.3 \mathrm{~B} \\
44.0 \pm 2.5\end{array}$ \\
\hline
\end{tabular}

aMeans followed by the same letters do not differ statistically from each other $(p>0.05)$ as indicated by the Tukey test.

Table 5. Longevity of bees fed on honey, beebread or cornbased diets derived from corn plants treated with fipronil or imidacloprid or left untreated at sowing.

\begin{tabular}{lll}
\hline Ingredients & & $\begin{array}{l}\text { Longevity } \\
\text { (days) }\end{array}$ \\
\hline Beebread & & $24.0 \mathrm{a}$ \\
Honey & Non-hybrid corn & $15.0 \mathrm{c}$ \\
& Non-hybrid corn + fipronil & $20.0 \mathrm{~b}$ \\
& Non-hybrid & $1.0 \mathrm{~b}$ \\
& corn + imidacloprid & $19.0 \mathrm{~b}$ \\
& Hybrid corn & $19.5 \mathrm{~b}$ \\
& Hybrid corn + Fipronil & $20.0 \mathrm{~b}$ \\
& Hybrid corn + Imidacloprid & $19.0 \mathrm{~b}$ \\
& Transgenic corn & $20.5 \mathrm{~b}$ \\
& Transgenic corn + Fipronil & $19.5 \mathrm{~b}$ \\
$\chi^{2}$-value & Transgenic corn + Imidacloprid & $19.0 \mathrm{~b}$ \\
$p$-value & 29.3 I & \\
\hline
\end{tabular}

(Tables 3 and 4), resulting in metabolic losses due to the importance of these proteins for bee and colony development.

Lipophorin concentration was over $25 \%$ lower in honey bees fed on maize whose seeds were treated with imidacloprid compared with honey bees fed on maize whose seeds were not treated with insecticides (Table 3). Imidacloprid acts as a neurotoxin and binds to the nicotinic acetylcholine receptor of insects (Boucias, Stokes, Storey, \& Pendland, 1996). As it is a systemic insecticide, bees can consume contaminated food or have direct contact with contaminated food as a consequence of imidacloprid drift due to aerial application drift or mechanical stirring of contaminated soil (Greatti, Sabatini, Barbattini, Rossi, \& Stravisi, 2003). Assessing the potential effects of CCRI4I cotton pollen on honey bees, Han, Niu, Lei, Cui, and Desneux (20l0b) concluded that, while imidacloprid did not promote an immediately obvious detrimental effect, it reduced honey bees' visual learning capacities and degraded their olfactory learning performances.

Protein quality significantly influenced honey bee longevity. Bees fed on beebread lived nine days longer compared with bees fed solely honey (Table 5). Bees fed on maize-based diets lived significantly longer than those fed on honey alone, but significantly less than those fed on beebread (Table 5). Among bees fed on the different corn diets, with and without pesticide seed treatment, longevity did not differ (Table 5). Many authors have previously related that transgenic crops do not impact on honey bee longevity (Arpaia, 1996; Malone, Burgess, \& Stefanovic, 1999; Malone, Todd, Burgess, \& Christeller, 2004; Ramirez-Romero, Chaufaux, \& Pham-Delègue, 2005). Though the pesticides did not affect longevity, there is concern that accumulation in the soil after consecutive plantings could have a greater effect on bees.

Although artificial diets may be prepared from select ingredients to improve a colony's health, AG8088YG (transgenic) maize must be avoided in addition to any other type of maize treated with imidacloprid at sowing. Additionally, an artificial diet must be prepared considering the nutritional value of the diet's ingredients, as well as its genetic traits and cultivation mode with respect to the use of agrochemicals.

\section{Conclusions}

Maize should not be used as the only supplemental dietary protein ingredient for honey bee colonies.

The use of transgenic maize from cultivar AG8088YG as an ingredient of a protein diet reduced total hemolymph protein concentration, especially affecting the transport and storage proteins lipophorin and vitellogenin. Therefore, the use of transgenic maize for honey bee diets should be avoided.

The use of maize, transgenic or not, treated with imidacloprid at sowing should also be avoided, as it promotes lower levels of lipophorin in the hemolymph of honey bees.

\section{Disclosure statement}

No potential conflict of interest was reported by the authors.

\section{Funding}

This work was supported by grants from the Pró-Reitoria de Pesquisa (PROPe)-Universidade Estadual Paulista (UNESP) and CAPES. 


\section{ORCID}

Daniel Nicodemo (D) http://orcid.org/0000-000 I-6594-579I

David De Jong (D) http://orcid.org/0000-0003-2/31-9988

Joyce Mayra Volpini de Almeida (D) http://orcid.org/0000-00031916-5887

Lucas Aparecido Manzani Lisboa (D) http://orcid.org/0000-000I$9013-232 X$

\section{References}

Arpaia, S. (1996). Ecological impact of Bt-transgenic plants: I. Assessing possible effects of CrylllB toxin on honey bee (Apis mellifera L.) colonies. Journal of Genetics and Breeding, 50, 315-319.

Alqarni, A.S. (2006). Influence of some protein diets on the longevity and some physiological conditions of honey bee Apis mellifera L. workers. Journal of Biological Sciences, 6, 734-737. doi: I0.3923/jbs.2006.734.737

Amdam, G.V., Aase, A.L., Seehuus, S.C., Kim Fondrk, M.K., Norberg, K., \& Hartfelder, K. (2005). Social reversal of immunosenescence in honey bee workers. Experimental Gerontology, 40, 939-947.

Amdam, G.V., Norberg, K., Hagen, A., \& Omholt, S.W. (2003). Social exploitation of vitellogenin. Proceedings of the National Academy of Sciences, 100, 1799-1802.

Amdam, G.V., Simões, Z.L.P., Hagen, A., Norberg, K., Schroder, K., Mikkelsen, O., ... Omholt, S.W. (2004). Hormonal control of the yolk precursor vitellogenin regulates immune function and longevity in honey bees. Experimental Gerontology, 39, 767-773.

Andrei, E. (20I3). Compêndio de defensivos agrícolas guia prático de produtos fitossanitários para o uso agrícola. São Paulo: Organização Andrei.

Association of Official Analytical Chemists. (1990). Official methods of analysis of the Association of Official Analytical Chemists. Arlington: Author.

Bitondi, M.M.G., \& Simões, Z.L.P. (1996). The relationship between level of pollen in the diet, vitellogenin and juvenile hormone titres in Africanized Apis mellifera workers. Journal of Apicultural Research, 35(I), 27-36. doi:10.1080/ 00218839.1996 .11100910

Boucias, D.G., Stokes, C., Storey, G., \& Pendland, J.C. (1996). The effect of imidacloprid on the termite Reticulitermes flavipes and its interaction with the mycopathogen Beauveria bassiana. Pflanzenschutz-Nachrichten Bayer, 49, I03-144.

Bradford, M.M. (1976). A rapid and sensitive method for the quantitation of microgram quantities of protein utilizing the principle of protein-dye binding. Analytical Biochemistry, 72, 248-254.

Brodschneider, R., \& Crailsheim, K. (2010). Nutrition and health in honey bees. Apidologie, 4I, 278-294.

Chino, H., \& Downer, R.G. (1982). Insect hemolymph lipophorin: A mechanism of lipid transport in insects. Advances in Biophysics, 15, 67-92.

Cock, M.J.W., Biesmeijer, J.C., Cannon, R.J.C., Gerard, P.J., Gillespie, D., Jiménez, J.J., ...Raina, S.K. (20I3). The implications of climate change for positive contributions of invertebrates to world agriculture. CAB Reviews: Perspectives in Agriculture, Veterinary Science, Nutrition and Natural Resources, 8, I-48.

Crailsheim, K. (1990). The protein balance of the honey bee worker. Apidologie, 21, 417-429.

Cremonez, T.M., De Jong, D., \& Bitondi, M.M.G. (1998). Quantification of hemolymph proteins as a fast method for testing protein diets for honey bees (Hymenoptera: Apidae). Journal of Economic Entomology, 91, I284-1289.
Decourtye, A., Armengaud, C., Renou, M., Devillers, J., Cluzeau, S., Gauthier, M., \& Pham-Delègue, M. (2004). Imidacloprid impairs memory and brain metabolism in the honey bee (Apis mellifera L.). Pesticide Biochemistry and Physiology, 78, 83-92.

De Groot, A.P. (1953). Protein and amino acid requirements of the honey bee (Apis mellifera L.). Physiology Comparate et Oecologia, 3, 197-285.

De Jong, D., da Silva, E.J., Kevan, P.G., \& Atkinson, J.A. (2009). Pollen substitutes increase honey bee haemolymph protein levels as much as or more than does pollen. Journal of Apicultural Research, 48(I), 34-37.doi: 10.3896/IBRA.I.48.1.08

de Maagd, R.A., Bravo, A., \& Crickmore, N. (200I). How Bacillus thuringiensis has evolved specific toxins to colonize the insect world. Trends in Genetics, 17, 193-199.

Duan, J.J., Marvier, M., Huesing, J., Dively, G., \& Huang, Z.Y. (2008). A Meta-Analysis of Effects of Bt Crops on Honey Bees (Hymenoptera: Apidae). PLoS ONE, 3. doi:10.137I/ journal.pone.0001415

El Hassani, A.K., Dacher, M., Gauthier, M., \& Armengaud, C. (2005). Effects of sublethal doses of fipronil on the behavior of the honey bee (Apis mellifera). Pharmacology Biochemistry and Behavior, 82, 30-39.

Ellis, A.M., \& Hayes, G.W., Jr. (2009). An evaluation of fresh versus fermented diets for honey bees (Apis mellifera). Journal of Apicultural Research, 48(3), 215-216. doi:10.3896/ IBRA.I.48.3.II

Gaucho: Insecticide. Leaflet of insecticide. (1996). São Paulo: Bayer S.A. Retrieved April 6, 2017, from http://www.ada par.pr.gov.br/arquivos/File/defis/DFI/Bulas/Inseticidas/GAU CHO.pdf

Greatti, M., Sabatini, A.G., Barbattini, R., Rossi, S., \& Stravisi, A. (2003). Risk of environmental contamination by the active ingredient imidacloprid used for corn seed dressing: Preliminary results. Bulletin of Insectology, 56, 69-72.

Han, P., Niu, C.Y., Lei, C.L., Cui, J.J., \& Desneux, N. (20I0a). Quantification of toxins in a CrylAc + CpTI cotton cultivar and its potential effects on the honey bee Apis mellifera L. Ecotoxicology, 19, 1452-1459.

Han, P., Niu, C.Y., Lei, C.L., Cui, J.J., \& Desneux, N. (20I0b). Use of an innovative T-tube maze assay and the proboscis extension response assay to assess sublethal effects of GM products and pesticides on learning capacity of the honey bee Apis mellifera L. Ecotoxicology, 19, 1612-1619.

Haydak, M.H. (1970). Honey bee nutrition. Annual Review of Entomology, 15, 143-156.

Herbert, E.W., Jr. (1992). Honey bee nutrition. In J.M. Grahan (Ed.), The hive and the honey bee (pp. 197-233). New York, NY: Dadant \& Sons.

Herbert, E.W., Jr., \& Shimanuki, H. (1978). Chemical composition and nutritive value of bee-collected and bee-stored pollen. Apidologie, 9, 33-40.

Hersch, M.I., Crewe, R.M., Hepburn, H.R., Thompson, P.R., \& Savage, N. (1978). Sequential development of glycolytic competence in the muscles of worker honey bees. Comparative Biochemistry and Physiology - Part B, 6I, 427-43I.

Huang, Z. (2010). Honey bee nutrition. American Bee Journal, 150, 773-776.

IBGE. (20I6). Levantamento sistemático da produção agrícola. Rio de Janeiro: IBGE.

Iwasa, T., Motoyama, N., Ambrose, J.T., \& Roe, R.M. (2004). Mechanism for the differential toxicity of neonicotinoid insecticides in the honey bee, Apis mellifera. Crop Protection, 23, 37I-378.

Johnson, R.M., Ellis, M.D., Mullin, C.A., \& Frazier, M. (2010). Pesticides and honey bee toxicity-USA. Apidologie, $4 I$, 3|2-33|. 
Knopper, L.D., Dan, T., Reisig, D.D., Johnson, J.D., \& Bowers, L.M. (20I6). Sugar concentration in nectar: A quantitative metric of crop attractiveness for refined pollinator risk assessments. Pest Management Science, 72, I807-1812.

Laemmli, U. K. (1970). Cleavage of structural proteins during the assembly of the head of bacteriophage T4. Nature, 227, 680-685.

Malone, L.A., Burgess, E.P.J., \& Stefanovic, D. (1999). Effects of a Bacillus thuringiensis toxin, two Bacillus thuringiensis biopesticide formulations, and a soybean trypsin inhibitor on honey bee (Apis mellifera L.) survival and food consumption. Apidologie, 30, 465-473.

Malone, L. A., \& Pham-Delègue, M. (200I). Effects of transgene products on honey bees (Apis mellifera) and bumble bees (Bombus sp.). Apidologie, 32, 287-304.

Malone, L.A., Todd, J.H., Burgess, E.P.J., \& Christeller, J.T. (2004). Development of hypopharyngeal glands in adult honey bees fed with a Bt toxin, a biotinbinding protein and a protease inhibitor. Apidologie, 35, 655-664.

Maurizio, A. (1954). Pollenernährung und Lebensvorgänge bei der Honigbiene (Apis mellifica L.). Landwirtschaftliches Jahrbuch der Schweiz, 62, II5-182.

Mayer, D.F., \& Lunden, J.D. (1999). Field and laboratory tests of the effects of fipronil on adult female of Apis mellifera, Megachile rotundata and Nomia melanderi. Journal of Apicultural Research, 38(3-4), 191-197.doi:10.1080/ 00218839.1999 .11101009

Melhorança, A.L., Coelho, A.M., Andrade, C.L.T., Casela, C.L., Guimarães, D.P., Karam, D., ... Alves, V.M.C. (2010). Pragas. In J.C. Cruz (Ed.). Cultivo do milho. Brasília: EMBRAPA Milho e Sorgo. Retrieved April 15, 2017, from http://www. cnpms.embrapa.br/publicacoes/milho_6_ed/pragas.htm

Nicodemo, D., Maioli, M.A., Medeiros, H.C.D., Guelfi, M., Balieira, K.V.B., De Jong, D., \& Mingatto, F.E. (20I4). Fipronil and imidacloprid reduce honey bee mitochondrial activity. Environmental Toxicology and Chemistry, 33, 20702075.

Pernal, S.F., \& Currie, R.W. (2000). Pollen quality of fresh and I-year-old single pollen diets for worker honey bees (Apis mellifera L.). Apidologie, 3I, 387-409.

Qaim, M. (2009). The economics of genetically modified crops. Annual Review of Resource Economics, I, 665-694.

Raij, B.V., Cantarella, H., Quaggio, J.A., \& Furlani, A.M.C. (1997). Recomendações de adubação e calagem para o Estado de São Paulo. Campinas: IAC.

Ramirez-Romero, R., Chaufaux, J., \& Pham-Delègue, M.H. (2005). Effects of CrylAb protoxin, deltamethrin and imidacloprid on the foraging activity and the learning performances of the honey bee Apis mellifera, a comparative approach. Apidologie, 36, 60I-6II.
Ramirez-Romero, R., Desneux, N., Decourtye, A., Chaffiol, A., \& Pham- Delègue, M. (2008). Does Cry IAb protein affect learning performances of the honey bee Apis mellifera $\mathrm{L}$. (Hymenoptera, Apidae)? Ecotoxicology and Environmental Safety, 70, 327-333.

Regent 800 WG: Insecticide. (2002). São Bernardo do Campo: BASF S.A. Retrieved April 6, 2017, from http://www.agro. basf.com.br/agr/ms/apbrazil/pt_BR/content/APBrazil/solu tions/insecticides/insecticides_product/Regente_800_WG

Roat, T.C., Carvalho, S.M., Nocelli, R.C.F., Silva-Zacarin, E.C.M., Palma, M.S., \& Malaspina, O. (20I3). Effects of sublethal dose of fipronil on neuron metabolic activity of africanized honey bees. Archives of Environmental Contamination and Toxicology, 64, 456-466.

Rostagno, H.S., Albino, L.F.T., Donzele, J.L., Gomes, P.C., Oliveira, R.F., Lopes, D.C., ... Barreto, S.L.T. (2005). Tabelas brasileiras para aves e suínos: Composição de alimentos e exigências nutricionais. Viçosa: Universidade Federal de Viçosa.

Sabugosa-Madeira, J.B., Abreu, I., Ribeiro, H., \& Cunha, M. (2007). Bt transgenic maize pollen and the silent poisoning of the hive. Journal of Apicultural Research, 46(I), 57-58. doi:I0.1080/002I8839.2007.III 01367

SAS Institute. (2003). SAS user's guide. (Version 9.I ed.). Cary, NC: SAS Inst. Inc.

Silva, D.J., \& Queiroz, A.C. (2006). Análise de alimentos: Métodos químicos e biológicos. Viçosa: UFV.

Simon-Delso, N., Amaral-Rogers, V., Belzunces, L.P., Bonmatin, J.M., Chagnon, M., Downs, C., ... Wiemers, M. (20I5). Systemic insecticides (neonicotinoids and fipronil): Trends, uses, mode of action and metabolites. Environmental Science and Pollution Research International. doi: 10.1007/s I I 356-0 14-3470-y

Somerville, D. (2005). Fat bees skinny bees: A manual on honey bee nutrition for beekeepers. Goulburn: Rural Industries Research and Development Corporation.

Tang, M., He, X., Luo, Y., Ma, L., Tang, X., \& Huang, K. (2013). Nutritional assessment of transgenic lysine-rich maize compared with conventional quality protein maize. Journal of the Science of Food and Agriculture, 93, 1049-1054.

Tomlinson, S., Dixon, K.W., Didham, R.K., \& Bradshaw, S.D. (2017). Landscape context alters cost of living in honey bee metabolism and feeding. Proceedings of the Royal Society-Part B. doi: I0.1098/rspb.2016.2676

Vidal, S., Kuhlmann, U., \& Edwards, C.R. (2005). Western corn rootworm: Ecology and management. Wallingford: $C A B$ International.

Winston, M.L. (1987). The biology of the honey bee. London: Harvard University Press.

Wolfenbarger, L.L.I., \& Phifer, P.R. (2000). The ecological risks and benefits of genetically engineered plants. Science, 290, 2088-2093. 